\title{
The Significance of Shendu in the Interpretation of Classical Learning and ZHU Xi's Misreading
}

\author{
Tao Liang
}

Published online: 11 July 2014

(C) The Author(s) 2014. This article is published with open access at Springerlink.com

\begin{abstract}
According to recently excavated bamboo and silk material, the idea of $d u$ 獨 in the concept shendu 慎獨 does not refer to a spatial notion of dwelling in solitude or a solitary dwelling; rather it is the state before having made contact with external things, or the state "before feelings are aroused" (weifa 未發) of the inner heart/mind. It refers to internal thoughts and volitions, or "casting aside external sensations" (sheti 舍體). Shen 慎 should be glossed in accordance with the Erya 爾雅 (Approaching Elegance), rendering it as "sincerity" (cheng 誠). Shendu then means to "cause one's will to be sincere” (chengqiyi 誠其意). ZHENG Xuan 鄭玄, in explaining shendu as being “cautious of the actions one performs in private" (shen qi xianju suowei 慎其閒居所為), completely strayed from the original meaning as found in the bamboo-silk texts. ZHU Xi 朱喜, seeing the insufficiencies of ZHENG Xuan's interpretation of shendu, broadened the meaning of $d u$, and in particular added a spiritual meaning to it. However, due to influence by ZHENG Xuan, ZHU Xi still preserved some misreadings of the term; especially in his interpretation of shendu in the Daxue 大學 (Great Learning) and Zhongyong 中庸 (Doctrine of the Mean). Considering that the Neo-Confucian methods of cultivation embodied in the ideas of "abiding in reverence and enriching the self" (jujing hanyang 居敬涵養), and “being refined and focused" (weijing weiyi 惟精惟一) actually accorded more with the original meaning of shendu, ZHU Xi's misreading of shendu is indirectly related to the loss of its original meaning due to the broken transmission of the ancient texts.
\end{abstract}

Keywords ZHU Xi 朱喜.Shendu 慎獨· Causing one’s will to be sincere · Casting aside external sensations

Shendu 慎獨 is an important concept in Confucian studies. Most interpreters define it as, "While in a solitary dwelling, one is able to be cautious and conscientious" (Editorial Division of Sea of Words 1965: 1637). Some explain it as an injunction

Tao LIANG $(\square)$

School of Chinese Classics, Renmin University of China, Zhongguancun Street No. 59, Haidian District, Beijing, China 100872

e-mail: liangtao1965@163.com 
where "the things one does while dwelling in solitude, with no one watching, should be performed cautiously and conscientiously" (Editorial Division of Source of Words 1997: 624). However, newly unearthed silk and bamboo manuscripts reveal this position to be the misunderstanding of later interpreters and not the original meaning of shendu. Although this misunderstanding started with ZHEng Xuan 鄭玄 in the Eastern Han 漢 dynasty, ZHU Xi 朱喜 served to perpetuate it. This essay will analyze shendu's original meaning and ZHU Xi's thought on shendu.

\section{The Original Meaning of Shendu and Zheng Xuan's Annotation}

If not for the discovery of Mawangdui 馬王堆 in the 1970s (see Ancient Literature Research Office 1980) and Guodian 郭店 in the 1990s (see Jingmen Museum 1998), there would probably still be a long period of time before we would know the original meaning of shendu. Unearthed separately in both finds, the text of the Wuxing 五行 (Five Principles) discusses the concept of shendu and aids us in understanding its original meaning. One passage of Chapter 8 of the Wuxing reads,

"The turtledove in the mulberry tree, its children are seven.

The handsome profound person, his demeanor is one."

Able to be one, he is then able to be a profound person. The profound person acts

to shenqidu 慎其獨. (Holloway 2002: 168-169; with modifications)

The accompanying commentary's explanation of shendu in this passage is,

The phrase "Able to be one" means that he is able to make many become one. "Making many become one" refers to being able to make the five become one.... The phrase "shenqidu" speaks of casting aside the five and performing the act to shen one's heart/mind. [The profound person] must be $d u$ and then become one. "One" refers to the five becoming (one) heart/mind. Afterward, virtue is obtained. (Holloway 2002: 168-169; with modifications)

The "five" spoken of here allude to "benevolence, rightness, ritual propriety, wisdom, and sagacity." According to what is laid out in the Wuxing these are five kinds of "movements of virtuous power" that "form within"-meaning that they take shape in the heart/mind. From the perspective of the Wuxing, although these five virtues are "formed within" they are still undetermined - having not yet been truly put in sync with the heart/mind. This is why the text says, "'One' refers to the five becoming (one) heart/mind." Chapter 2 of the Wuxing also explains that, "The flow of virtuous power of all five [virtues], being in harmony, is [true] virtuous power" (my own translation). When benevolence, rightness, ritual propriety, wisdom, and sagacity are harmonized and fully integrated - becoming a holistic system - only then can they be found in the heart/mind, and only then can they be called "[true] virtuous power." Therefore, the shendu spoken of here actually refers to the single-minded devotion of the heart/ mind-its attentiveness. More specifically, it refers to the heart/mind's attitude of 
single-minded devotion to benevolence, rightness, ritual propriety, wisdom, and sagacity - the five "movements of virtuous power." The Wuxing, Chapter 8, also reads,

"The swallows go flying about, with their wings unevenly displayed.

The lady was returning [to her native state], and I escorted her far into the country.

I looked until I could no longer see her, and my tears fell down like rain."

Only when you are able to display your wings unevenly do you understand the utmost sadness. The profound person acts to shenqidu 慎其獨. (Holloway 2002: 168-169; with modifications)

The commentary explains this as follows,

The phrase "uneven" means not wearing a hemp-mourning belt. Not wearing a hemp-mourning belt [still] enables one to express the utmost sorrow. In mourning, [concerning oneself with] straitening the belt and decorating the collar can stifle sorrow. The deep interior [of the self], not found in the exterior, is what is called $d u$. Du means casting aside external sensations (sheti 舍體). (Holloway 2002: 168-169; with modifications)

Indeed, the things of this world are often like this. When people pay excessive attention to external circumstances, the real situation of the inner heart/mind cannot be naturally expressed. So the person who truly comprehends mourning rituals is able to transcend the external form of mourning attire and concern himself with the genuine feelings of the inner heart/mind. As the text states, "The deep interior [of the self], [is] not found in the exterior." From the perspective of the author of the commentary, this, then, is the meaning of $d u$. It is sheti 舍體, or casting aside the perceptions and impressions of the body's sensing external things, and returning to internal thoughts and volitions. Therefore, the notion of $d u$ in terms of shendu is not "a solitary dwelling" or "dwelling in solitude"; rather it is the psychological state of weifa 未發, or the state of not yet having made contact with things external to the self. It refers to internal thoughts and volitions. This meaning of $d u$ is also seen in Pre-Qin 秦 texts such as the "Dazongshi 大宗師” chapter of the Zhuangzi 莊子:

After three days, I was able to put the world outside myself. When I had put the world outside myself, I kept meditating for seven days more, and after that I was able to put things outside myself. When I had put things outside myself, I kept meditating for nine days more, and after that I was able to put life outside myself. After I had put life outside myself, I was able to achieve the brightness of dawn, and when I had achieved the brightness of dawn, I could see my own internality $(d u)$. After I had managed to see my own internality $(d u)$, I could do away with past and present, and after I had done away with past and present, I was able to enter where there is no life and no death. (Watson 1968: 82-83; with modifications)

The notion of xiand $u$ 見 (現) 獨 that Zhuangzi describes is somewhat similar to the idea of a transcendental deduction in phenomenology; namely it calls for abandoning one's 
natural attitude and intrinsic view of the world and returning to a pure $a$ priori consciousness. Xiandu, then, is to discover innate and a priori thoughts and volitions. The sense of $d u$ employed in this passage carries the same meaning as the one used in the Wuxing-both are used in the sense of "casting aside external sensations" (sheti). So although the notion of xiandu from the Zhuangzi has some substantive differences from the concept of shend $u$ in Confucianism, from the perspective of the psychological state, they are consistent. This consistency is obviously built on a common understanding of $d u$.

$D u$ can also act as a verb, meaning "to internalize." The commentary on Chapter 9 of the Wuxing explains,

There is the statement, "In the profound person's pursuit of virtue, there is the beginning but no end." The phrase "there is beginning" refers to the fact that he begins with his body. The phrase "but no end" means that he casts aside his body (sheqiti 舍其體) and internalizes his heart/mind (duqixin 獨其心). (Holloway 2002: 170; with modifications)

The $d u$ mentioned here is spoken of in terms of "internalizing." To " $d u$ one's heart/ mind" (duqixin 獨其心) is to internalize the heart/mind. The idea of "internalizing the heart/mind" also appears in other Pre-Qin texts in conjunction with discussions about shendu. The "Liqi 禮器” (Ritual Vessel) chapter of the Liji 禮記 (Book of Rites), for instance, recounts,

When one values paucity in the performance of rites it is because he internalizes his heart/mind (neixin 內心). The highest level of virtue one produces is refined and minute. When observing things in the world, none seem to measure up to this virtue. As such, how could paucity not be valued? This is why the profound person acts to shenqidu.

ZHENG Xuan's annotation of neixin 內心 is “to focus one's heart/mind on the internal; as one's supreme virtue is in the interior". The "Liqi" chapter is consistent with the Wuxing in using shendu along the lines of "internalizing the heart/mind." This, then, is most likely the original meaning of shendu.

So, to recapitulate, what exactly is shendu? The Erya explains that shen means "genuine or sincere" (cheng 誠); following the commentary on the Wuxing, $d u$ refers to "sheti," or internal thoughts and volitions. Therefore, shendu means to make one's will sincere. In this time period, shendu was already a popular term. Its meaning was widely known and people often interpreted and explained it in different expressions - the Wuxing speaks of shendu as "being able to be one (heart/ mind)", the "Liqi" chapter speaks of it as "internalizing the heart/mind," and so on. However, regardless of whether shendu is understood as "being able to be one (heart/mind)" or "internalizing the heart/mind," it similarly means to make one's will sincere. The different expressions are simply differences in concrete forms of articulation. As such, through the Wuxing we discover one important meaning of $d u$; we also come up with a more reasonable interpretation of shendu, and conclude a long-standing and unresolved controversy in intellectual history. 
There may be scholars who will take issue with this. They may ask, "Interpreting shendu as 'causing one's will to be sincere' is specific to the Wuxing, but was it the common understanding of the time? Are we to say that the Daxue and Zhongyong also use shendu in the same sense?" The answers to these questions are certain. The appearances of shendu in Pre-Qin texts uniformly refer to causing one's will to be sincere. The Daxue and Zhongyong are no exception. Let us first look at the appearance of shendu in the Daxue:

The notion of causing one's will to be sincere means to not deceive oneself. This happens when we do things such as despise despicable fragrances and are fond of pleasant sights. These are things we naturally enjoy. Therefore, the profound person must act to shenqidu. There is no evil to which the uncultivated person, dwelling retired, will not manifest; but when he sees a profound person, he instantly tries to disguise himself, concealing his evil, and displaying what is good. When others catch sight of him they see his inner thoughts. Of what use is his disguise? This is the meaning of the saying - "When sincerity is within, it will take shape without." Therefore, the profound person must act to shenqidu. (Legge 1971: 366-367; with modifications)

The phrase shenqidu appears twice in this passage. The first appearance clearly refers to causing one's will to be sincere. The latter appearance, however, requires some analysis in light of the phrase that precedes it. That phrase basically explains that the uncultivated person all too often delights in doing bad things; but after seeing the profound person he tries to disguise himself - "concealing his evil, and displaying what is good." The problem, however, is that people's interior and exterior tend to be consistent-so bad thoughts and bad ideas often manifest themselves in outward action- "When others catch sight of him they see his inner thoughts." Forcing oneself to feign proper comportment is unfeignable. Only "when sincerity is within" can "it take shape without," so shendu must be realized in maintaining "sincerity within."

So we can see here that the latter usage of shenqidu is the same as the former. They both mean to cause one's will to be sincere. However, while emphasizing the sincerity of the will, the notion of shendu used in the Daxue also takes into consideration the effects of external elements. This is why the text goes on to quote Zengzi 曾子, “'What ten eyes behold, and what ten hands point to, is to be regarded with reverence!' Riches adorn a house, and virtue adorns the person. The heart/mind is expanded, and the body is at ease. Therefore, the profound person causes his will to be sincere" (Legge 1971: 367; with modifications). In other words, as soon as the thoughts and volitions of the inner heart/mind manifest themselves on the exterior they will suffer the observation and critique of public opinion. Such being the case one should all the more cause one's will to be sincere. In comparison with the Wuxing and "Liqi," which emphasize "being able to be one" and "internalizing the heart/mind," the Daxue tends to be more comprehensive.

Shendu in the Daxue refers to causing one's will to be sincere, and shendu in the Zhongyong does likewise. The opening passage of the Zhongyong reads:

What Heaven has conferred is called human nature. To follow this nature is called the Way (dao 道). The regulation of this Way is called instruction. The Way may 
not be left for an instant. If it could be left, it would not be the Way. On this account, the profound person does not wait till he sees things to be cautious, nor till he hears things to be apprehensive. There is nothing more visible than what is secret, and nothing more manifest than what is minute. Therefore the profound person acts to shenqidu. (Zheng 1980: 1625)

When the author mentions, "The Way may not be left for an instant. If it could be left, it would not be the Way," the lines that follow- "On this account, the profound person does not wait till he sees things to be cautious, nor till he hears things to be apprehensive. There is nothing more visible than what is secret, and nothing more manifest than what is minute. Therefore the profound person acts to shenqidu" - are actually an explanation of the initial line. Therefore, what dao 道 specifically refers to here becomes central in understanding the notion of shendu. Because of what follows this phrase, when the text discusses the notion of being "unperturbed in the midst of daily affairs" (zhongyong 中庸), quoting Confucius in saying things such as, "The profound person is unperturbed in the midst of daily affairs, but the uncultivated person goes against this and is perturbed in the midst of daily affairs. The profound person is unperturbed in the midst of daily affairs because he remains unperturbed in any situation. The uncultivated person is perturbed in the midst of daily affairs because he is without caution" (Zheng 1980: 1626), it tends to cause people to all too easily think that dao refers to the "way" of being unperturbed in the midst of daily affairs, or is at least related to the notion of being unperturbed in the midst of daily affairs. From this perspective shendu would refer to being careful of one's actions when in a solitary dwelling. However, as we know, the current text of the Zhongyong is actually comprised of two parts. Passage two (following the numbering laid out in Zhu 1994: 15-38) to the first half of passage twenty, which concludes with the line, "The means by which they enact it is one" (suoyi xingzhi zhe yi ye 所以行之者一也), is the first part of the Zhongyong. Passage one and the second half of passage twenty, which begins with the phrase, "In all things, success depends on previous preparation" (fanshi yu ze li 凡事豫 則立), down through the end of the text is the second part of the Zhongyong (Legge 1971: 411; with modifications). The first part primarily discusses the notion of being unperturbed in the midst of daily affairs. The second part primarily discusses the concept of “completion and illumination" (chengming 誠明). The compilation of these two parts into one text is actually a later redaction (Liang 2000). The dao mentioned in the first passage, "The Way may not be left for an instant," should not be read in relation to the second passage; but rather in relation to the twentieth passage, which begins with, "Sincerity is the Way of Heaven" (cheng zhe, tian zhi dao 誠者, 天之道). The dao mentioned in the twenty-first passage also refers to sincerity- "Sincerity is that which is self-completing, and the Way is self-guiding" (cheng zhe zicheng ye, er dao zidao ye 誠者自成也, 而道自道也). So the line, “The Way may not be left for an instant," means to constantly maintain a state of sincerity in the inner heart/mind. When compared with the notion of "causing one's will to be sincere" from the Daxue, the meaning is the same.

Since the critique might be leveled that this analysis moves by means of inference, another, more direct piece of evidence is helpful. LIU Xiang 劉向, in the "Jingshen 敬慎" (Reverence and Caution) chapter of the Shuoyuan 說苑 (Garden of Persuasions) explains, 
The essentials of preservation and desolation, and calamity and fortune, lie within the self. The sage gives weight to prohibitions, and is respectful and cautious concerning that which is otherwise not given attention. The Zhongyong says, "There is nothing more visible than what is secret, and nothing more manifest than what is minute. Therefore the profound person acts to shenqidu." There is a proverb that says, "Be sincere, without disgrace. Be considerate, without humiliation." Not being sincere or considerate while preserving the self and perfecting the state is indeed difficult. An ode expresses this meaning: "Anxious and careful, as if on the edge of a deep hollow, as if walking on thin ice." (Liu 1985: 95)

This passage clearly mentions the Zhongyong, explaining that the notion of shendu it discusses indeed comes from it. However, what is worth paying attention to here, despite the fact that it omits the phrase, "The Way may not be left for an instant," is that it first quotes a proverb saying, "Be sincere, without disgrace. Be considerate, without humiliation," and then recounts, "Not being sincere or considerate while preserving the self and perfecting the state is indeed difficult," indicating that the notion of shendu found in the Zhongyong is primarily spoken of in regard to sincerity. This, then, is a fact that everyone of the time commonly recognized. At the same time it also explains that our analysis of the Zhongyong is indeed a legitimate one.

Furthermore, the Zhongyong, in much the same way as the Daxue, while emphasizing a sincere will, also pays attention to external environmental factors. Therefore, in the phrase "The Way may not be left for an instant," which precedes the sentences "On this account, the profound person does not wait till he sees things, to be cautious, nor till he hears things, to be apprehensive. There is nothing more visible than what is secret, and nothing more manifest than what is minute," the notions of "not seeing" and "not hearing" refer to thought and consciousness, or the psychological condition of the inner heart/mind having yet to come into contact with external things. The notions of "nothing more visible than what is secret" and "nothing more manifest than what is minute" in the latter phrase refer to the condition of consciousness and thought already in contact with external things and manifest on the outside. In both circumstances one must be cautious and fearful of "not leaving the way"-always being mindful of the sincerity of the inner heart/mind. The difference between this and the Daxue is that the Zhongyong does not emphasize the effects that those with whom one publicly interacts will have on shendu. Instead it mentions, "There is nothing more visible than what is secret, and nothing more manifest than what is minute," implying that when in a solitary dwelling or dwelling in solitude (i.e., in secret), one should not allow bad thoughts and ideas to manifest themselves in minor affairs (i.e., the minute). However, regardless of whether it is the notion of "what ten eyes behold, and what ten hands point to" in the Daxue, or the concepts of "secret" and "minute" in the Zhongyong, their explanation and emphasis on shendu both maintain that the primary significance of the concept is "causing one's will to be sincere."

Following the analysis conducted above, the notion of $d u$ in Pre-Qin texts usually refers to "casting aside external sensations"; it also refers to paying attention to one's inner thoughts and volitions. The notion of $d u$ when used in the context of shendu is employed with this meaning. Shendu, then, is to cause one's will to be sincere. If one wants to cause one's will to be sincere it would be because one understands that inner thoughts and volitions often determine and influence outer action. Whatever thoughts 
and volitions one has on the inside, one will have similar expressions on the outside. Therefore, as a method of cultivation shendu emphasizes that one must first correct the inner thoughts and volitions - putting an end to the appearance of bad actions from their roots and sources. Indeed, Confucianism is a school of thought that emphasizes “introspection” (neixing 內省).

However, in accordance with the loss of the Wuxing, the meaning of $d u$ as "casting aside external sensations" was gradually forgotten, and more and more became understood as a solitary dwelling or dwelling in solitude. As such, the meaning of shendu underwent a transformation. This is evident in ZHENG Xuan's annotation on the phrase from the Zhongyong that reads, "Therefore the profound person acts to shenqidu." He said,

Shendu is to be careful over what one does in closed quarters. The uncultivated person, when in secret, thinks that his words and actions will not be seen or heard, and so he completely expends his feelings. But if someone is actually observing him, these actions become apparent; even to the point of performing the [same] actions in public. (Zheng 1980: 1625)

ZHENG Xuan understood $d u$ as a solitary dwelling, or dwelling in solitude (i.e., closed quarters), and conceived shendu as referring to "being careful about one's actions in closed quarters." From his point of view, when one dwells in solitude or is in a solitary place, because the pressure of public opinion is temporarily nonexistent, a person with bad moral qualities will find it easy to stray from the bounds of moral standards and come to do things one would not normally do. This perception of shendu is an invitation to those dwelling in solitude to preserve their virtue and integrity - to privately better one's self. ZHENG Xuan's interpretation is not without its logic. An attempt to coherently interpret the face value of the characters could lead to such a reading. For these reasons, this interpretation has been widely accepted and become the authoritative interpretation of shendu.

ZHENG Xuan is a Han dynasty figure of great accomplishment in the field of classical learning. His understanding of shendu represents the view and knowledge of a particular time period. It explains that at least by the Eastern Han the notion of shendu had already undergone serious transformation. This transformation primarily manifests itself in $d u$, which originally referred to something internal and psychological, but came to be understood in a spatial sense of a solitary dwelling or dwelling in solitude. The psychological activity of "causing one's will to be sincere" also came to be understood as the external action of "being careful about one's conduct in closed quarters." This caused the Confucian tradition, with its emphasis on introspection, to undergo a certain degree of change in direction. It is within this setting that ZHU Xi put forth his interpretation of shendu.

\section{ZHU Xi's Interpretation of Shendu and Some Problems with It}

The sections above explain that when ZHU Xi carried out his interpretation of shendu, $d u$ had already changed from the notion of "casting aside external sensations" to "dwelling in solitude" or "a solitary dwelling." Shendu had also changed from "causing 
one's will to be sincere" to "being careful of actions done in closed quarters." Although this transformation of the notion shendu at face value accorded with reason-making it seem easier for people to understand; as soon as it is reinserted back into the texts, one can see the contradictions and inconsistencies this transformation brings. For instance, consider the line in the Daxue that reads, "The notion of causing one's will to be sincere means to not deceive oneself. This happens such as when we despise despicable fragrances and are fond of pleasant sights. These are things we naturally enjoy. Therefore, the profound person must act to shenqidu." Here, shendu is spoken of primarily in terms of "causing one's will to be sincere," and does not imply the notion of a solitary dwelling or dwelling in solitude. ZHU Xi recognized some aspects of these problems. Understanding the idea of $d u$ in this context became a central issue he wanted to resolve. ZHU Xi's commentary on this passage is:

The phrase chengqiyi refers to the beginning of self-cultivation. The word "not" is a prohibitive word. "Self deception" means knowing to do good and to remove bad, but the response of the heart/mind has yet to become genuine. Qian 謙 means to be "pleased" or "satisfied." $D u$ is the place others do not know about, but the self, alone, knows. It says that people who desire to cultivate the self know to do good and to remove evil, genuinely exerting effort, and stopping one's self deception, thereby enabling oneself to be disgusted with what is bad, like being disgusted with a bad smell, and fond of goodness, like being fond of a good sight. None of these efforts can be done away with. Simply seeking them [within the self], they will be found. In this manner, the self is self-pleasing and selfsatisfying. One cannot haphazardly follow along, searching for it externally, for the sake of pleasing others. So, being genuine or ingenuine depends on that place that others do not know about, but the self, alone, knows. Therefore, one must be cautious of this place, and guard its incipient tendencies. (Zhu 1994: 7)

ZHU Xi claimed that, "Sincerity means being genuine; and the will is that which the heart/mind issues forth." He took the phrase chengqiyi to mean "make real the issuance of the heart/mind, desiring that it be singly focused on good and without self-deception." From this perspective, when the thoughts of the inner heart/mind are incipient, and have yet to express themselves on the outside, "being genuine or ingenuine depends on that place that others do not know about, but the self, alone, knows. Therefore, one must be cautious of this place, and guard its incipient tendencies." According to ZHU Xi's understanding, shendu in this context refers to being cautious about the incipient forms ( $j i$ 幾) of thoughts; $d u$ refers to the state of the inner heart/mind others do not know, but only the self knows. In the passage above ZHU Xi defined $d u$ as "the place others do not know about, but the self, alone, knows." In addition to "the place others do not know about, but the self, alone, knows," referring to a solitary dwelling and dwelling in solitude, it also obviously refers to a notion of $d u$ where the thoughts of the inner heart/mind are incipient and no one else knows them. This understanding also appears in other portions of ZHU Xi's discourses. For instance,

It was asked, "Cautious solitude is not simply the place where 'ten eyes behold, and ten hands point.' Isn't it also the same as not being deceived in a dark place 
[i.e., when alone]"? The master agreed, and said, "This notion of $d u$ is not simply being alone $(d u)$ in this kind of place. Sitting with large groups of people, and having the heart/mind issuing forth thoughts - some good, some not good-is also a kind of solitary $(d u)$ place. (Zhu 1992a: 983)

Someone stated, "Shendu is nothing more than desiring to be unselfish." The master agreed. (Zhu 1992a: 68)

So in comparing ZHU Xi with ZHENG Xuan, the biggest difference in ZHU Xi's understanding of shendu is that he broadens the connotation of $d u$ to include psychological and internal significance. He does so obviously because of the insufficiencies of ZHENG Xuan's notion of "being careful about one's actions in closed quarters." It is an attempt to make a more reasonable explanation - an explanation on the basis of the meaning of the word shendu. However, if we say that ZHU Xi's interpretation of $d u$ in this passage, to a certain degree, resolves the contradiction between the interpretation of shendu put forth from the time of ZHENG Xuan and the actual meaning preserved in the text, then his understanding of the passage that follows- "When in closed quarters the uncultivated person does evil. ... So the profound person must act to shenqidu" - leads to a big problem. His annotation completely diverges from the original meaning of the text. ZHU Xi's commentary is as follows:

The term xian $j u$ 閒居 means a solitary dwelling. ... This speaks of the fact that in some situations the uncultivated person does what is not good and then seeks to hide these acts. It is not that he does not know that he should do good and remove evil; but rather that he lacks the ability to exert effort in doing this. He desires to conceal the evil, but in the end it cannot be concealed. He desires to pretend to do good, but in the end it is unfeignable. Indeed, what use is pretending! The profound person regards this with seriousness, and is cautious. Therefore he must be vigilant in solitude [shenqidu]. (Zhu 1994: 7)

According to ZHU Xi's understanding, this passage says that when alone, the uncultivated person often engages in bad activities; and when in the purview of a profound person he attempts to conceal his evil actions from being seen. It is not that the uncultivated person does not know he should enact good and avoid evil; it is just that as soon as he goes to a solitary place, with no one to keep an eye on him, an inclination to do evil arises and he lacks the strength to do what is right. Since pretending and concealing one's true self will not work, ZHU $\mathrm{Xi}$ urges us to make the commitment to be vigilant in solitude (shenqidu), and to do good when dwelling alone.

However, in direct accordance with what we previously analyzed, the phrase in the Daxue which reads, "When in closed quarters the uncultivated person does evil," is not the immediate reason to shenqidu; rather it explains the line, "When there is sincerity in the interior, it will manifest itself on the exterior." Simply put, "sincerity in the interior" is the essential meaning of shendu. Therefore, the passage above from ZHU Xi does not only deviate from the meaning found in the original text, it also causes the phrase "When there is sincerity in the interior, it will manifest itself on the exterior" to be 
excised from the meaning of the text - in effect, left without a home. ${ }^{1}$ This explains that in the thought of ZHU Xi, the notion of $d u$ in the concept of shendu refers primarily to dwelling in solitude or a solitary dwelling. Indeed, his interpretation did not break free from the understanding of shendu since the time of ZHENG Xuan.

This issue is also reflected in his comments on the phrase, "What ten eyes behold, and what ten hands point to." He stated, "This speaks of being in the midst of deep privacy (youdu 幽獨), yet the good and evil one does cannot be concealed. Indeed, one should be deeply fearful about this" (Zhu 1994: 7). One need only glance at this to see that ZHU Xi's explanation easily leads people astray. The surface meaning of the characters in the phrase, "What ten eyes behold, and what ten hands point to," obviously refers to a public place with numerous people, or the focal point and concern of public opinion. So how can it be said that it refers to "being in the midst of deep privacy"? In the original text the phrase, "What ten eyes behold, and what ten hands point to," is associated with the line, "When there is sincerity in the interior, it will manifest itself on the exterior," explaining that as soon as our internal thoughts and volitions are manifest on the outside, they are immediately met with the criticism and inspection of public opinion. Not only does this have nothing to do with "being in the midst of deep privacy," but its meaning is actually the opposite. So how did ZHU Xi tie the two together? In the Zhuzi Yulei 朱子語類 (Collected Sayings of ZHU Xi), he had a conversation explaining precisely this point:

Someone asked about the phrase, "What ten eyes behold, and what ten hands point to." ZHU Xi replied, "This follows from the meaning of the phrase that precedes it: 'When others catch sight of him they see his inner thoughts.' Not enacting them, [he thinks] others will not know, but it is as if they do know, and all see him as such. (Zhu 1992a: 73; emphasis mine.)

WEI Yuanshou 魏元壽 asked the paragraph from "ten eyes beholding” to "the heart/mind is expanded, and the body is at ease." ZHU Xi replied, "The notion of 'ten eyes beholding and ten hands pointing' is not about being fearful of being seen by people. Rather, although people do not know, oneself already knows and so the self is dreadfully fearful. How is this different from 'what ten eyes behold, and what ten hands point to'!" (Zhu 1992a: 73-74)

So actually, in ZHU Xi's view the notion of, "What ten eyes behold, and what ten hands point to," did not exist in reality. It was a kind of "hypothesis" - although surrounded by darkness and all alone, it was as if there were "ten eyes pointing and ten hands pointing." This fully explains that in ZHU Xi's thinking, $d u$ primarily refers to dwelling

\footnotetext{
${ }^{1}$ In the Zhuzi's Sayings of Four Books 朱子四書語類, ZHU Xi does discuss the issue of, "When there is sincerity in the interior, it will manifest itself on the exterior." For instance, he says, "The line that mentions, "Causing one's will to be sincere is being fond of goodness - like being fond of pleasant sights; and despising badness is like despising despicable fragrances' refers to genuine emotional dispositions. These genuine emotional dispositions take shape and appear on the exterior; so they can all be seen. It's like planting hemp or corn. When they grow, they will become hemp or corn. These are examples of the notion of, 'When there is sincerity in the interior, it will manifest it self on the exterior.' At the same time, though, one must be fearful of those unreached places that appear when alone; and so one must shendu" (Zhu 1992a: 67-68). In light of the last sentence, however, ZHU Xi obviously attached notions of dwelling in solitude or a solitary dwelling to understand the concept, "When there is sincerity in the interior, it will manifest itself on the exterior."
} 
in solitude or a solitary dwelling. Zhu's interpretation, therefore, does not spare in bringing about an extreme complication - ensuring that the meaning of the text is taken as "being in the midst of deep privacy."

Summarizing this line of thinking, ZHU Xi understood the notion of shen to mean "vigilance" or "fearfully cautious"; he understood the notion of $d u$ to refer to both the station of the internal heart/mind not known by others but only by oneself, and the physical space of dwelling in solitude or a solitary dwelling - although he saw it as primarily referring to the latter. As such, shendu became "cautious solitude" (jindu 謹 獨). As a matter of fact, ZHU Xi often explained shendu in terms of cautious solitude. His interpretation can actually be separated into two stages: first, being careful about the situation of the inner heart/mind when thoughts have just come about; and second, being fearfully cautious about dwelling in solitude or a solitary dwelling after these thoughts have "issued forth" (yifa 已發). In ZHU Xi's view both of these stages can be considered $d u$, as both are implied by his notion of cautious solitude.

In comparison with ZHENG Xuan's understanding of shendu, ZHU Xi's interpretation has some differences, and to a certain degree avoids contradicting the text. In view of the fact that all along it was impossible for him to escape the idea earlier people fell into of taking shendu as dwelling in solitude or a solitary dwelling, his understanding still fell a certain distance away from the original meaning of the term. Indeed, the notion of a heavily trafficked public setting - "What ten eyes behold, and what ten hands point to"-employed in the Daxue conveys quite the opposite meaning of dwelling in solitude or a solitary dwelling. More importantly, the notion of shendu in the Daxue is the same as that in the Wuxing and the "Liqi" - all referring to causing one's will to be sincere, or a condition of the inner heart/mind that is genuine and honest. Yet if we follow ZHU Xi's understanding, shendu is the work and method (gongfu 功夫) of causing one's will to be sincere. ZHU Xi actually has a few explanations. For instance,

Shendu is the work of causing the will to be sincere. In the process of extending knowledge the will begins to be sincere. Yet one is fearful that in the secret, remote, and solitary places [of the self], one's [will] is not yet fully sincere or genuine, and so one must shendu.

After knowledge has been fully extended, the will is sincere. But one remains fearful that the secret and remote places [within the self] have not been made genuine, and so one must inspect [the will] and be careful of it - causing it to be without the least bit of presumptuousness and brashness. Only then will the inner and the outer [dimensions of the self], the subtle and the apparent, be without the least degree of insincerity, and the self will be pleased and at ease. (Zhu 1992a: 67-68)

Shendu is not merely causing one's will to be sincere, but "the work of causing one's will to be sincere." It is "being fearful that in the secret, remote, and solitary places [of the self], one's [will] is not yet fully sincere or genuine" and so one must "inspect [the will] and be careful of it - causing it to be without the least bit of presumptuousness and brashness." This interpretation not only discounts the original meaning of shendu, but also diminishes its virtuous power as a practical method.

In his commentary on the Zhongyong, ZHU Xi also offers an explanation of the notion of shendu. Due to the fact that the received text has a number of problems, his 
understanding also presents a number of places that are worthy of discussion. After the lines, "The Way may not be left for an instant.... On this account, the profound person does not wait till he sees things to be cautious, nor till he hears things to be apprehensive," he comments,

“The Way" here means the principles ( $l i$ 理) things ought to operate by on a daily basis. They are the virtuous power of human nature and are contained in the heart/ mind. No thing does not have them, and no circumstance is without them. This is why the Way cannot be left for an instant. If it could be left, it would be external to things and therefore not be the Way. This is why the heart/mind of the profound person always preserves an attitude of reverence and awe. Even if not seen or heard, he does not dare neglect this. And so he preserves the natural patterns of Heaven and does not allow himself to leave it for even an instant. (Zhu 1994: 17)

According to our earlier investigation, dao in the phrase, "The Way may not be left for an instant" refers to "sincerity." All of the early Confucian texts reflect this idea. ${ }^{2}$ ZHU $\mathrm{Xi}$, however, interpreting this passage as "the principles things ought to operate by on a daily basis" has obviously conflated it with the notion of being "unperturbed in the midst of daily affairs" that appears in and after the second passage of the text. Although "the principles things ought to operate by on a daily basis" and "sincerity" are both rooted in the highest principle of heaven, and are "the virtuous power of human nature and are contained in the heart/mind"; notwithstanding, there is still an important difference between these two concepts. This interpretation by ZHU Xi severs the internal link between shendu in the Daxue and shendu in the Zhongyong, thereby making it impossible for people to see the original meaning of "causing one's will to be sincere."

After the lines, "There is nothing more visible than what is secret, and nothing more manifest than what is minute. Therefore the profound person acts to shenqidu," Zhu comments,

"Secret" refers to a dark and hidden place. "Minute" means imperceptible affairs. $D u$ is the place others do not know about, but the self, alone, knows. In speaking of being in the midst of deep secrecy and being involved in imperceptible affairs, although the traces of these things have yet to take shape, and are incipient, they have already begun to move forth; and although others do not know about these

\footnotetext{
2 Besides the passage from the “Jingshen 敬慎” chapter of the Shuoyuan 說苑, the “Bugou 不苟” chapter of the Xunzi 荷子 also mentions, “The profound person has attained the utmost virtuous power. He is silent and yet instructive. Without administering to others, he is considered caring. Without being angry he inspires awe. As such he accords with what is appointed [by Heaven] and acts to shenqidu. As for those who are good at enacting the Way, if they are not sincere [cheng], they will not be $d u$. If they are not $d u$ then [their virtuous power] will not take shape. If [their virtuous power] does not take shape, even if one begins endeavors by first creating them in one's heart/mind; and even though they appear in one's countenance, and can be heard in one's words, the people will never follow along. And if they do, they will indeed be full of suspicion" (Xun 2005: 105). The "Bugou" chapter's use of characters is similar in many places to the Zhongyong, and was obviously influenced by it. This chapter could possibly be an early writing of Xunzi, who at the time was under the influence of the Zisizi 子思子-Mencius school of thought. It should therefore reflect the original meaning of shendu. See also Liang 2002.
} 
things, and the self, alone, knows; of all the affairs in the world, none are more obvious and plain to see than these. This is why the profound person is always fearful and apprehensive; and because of this he is all the more cautious. Therefore, stop selfish desires before they sprout, and do not allow them to grow in those secret and minute places [of the self]. Do this long before one has fallen well off the Way. (Zhu 1994: 18)

Here, ZHU Xi's understanding is the same as in his interpretation of the Daxue-shendu refers to a cautious solitude. However, because ZHU Xi understood dao in the previous line as "the principles things ought to operate by on a daily basis," it is still at odds with the appearance of shendu in the Daxue. Shendu in the Daxue referred to "causing one's will to be sincere," which Zhu took as "the work of causing one's will to be sincere." The notion of shendu in the Zhongyong he raises in connection with revering "the principles things ought to operate by on a daily basis" which "no thing does not have, and no circumstance is without." These two notions, in their specific contexts, are not the same. What is more important is that shendu in the Zhongyong is raised in connection with the entire line that contains the phrase, "The Way may not be left for an instant"; and although the line, "There is nothing more visible than what is secret, and nothing more manifest than what is minute," is an explanation and emphasis of what came before, ZHU Xi, however, understood shend $u$ in this case to merely refer to the latter line- "There is nothing more visible than what is secret, and nothing more manifest than what is minute." This scenario is reflected in a few of his recorded conversations. For instance:

The passage that speaks of being attentive and apprehensive should be separated into two parts. Being afraid and apprehensive over what one does not see, and fearful and apprehensive over what one does not hear is like listening for that which has no voice and looking for that which has no form. It is meant to stop inappropriate feelings before they take their course. Cautious solitude is to scrutinize feelings as they take their course, and thereby investigate their incipience.

HuANG Hao 黃影 said, “The acts of being attentive and apprehensive should be taken together to express the work and method [of making the will sincere]. Cautious solitude is to work harder in situations where one is anxious. One is the warp. One is the woof. Together they make cloth." The master agreed.

Be attentive, cautious, fearful, and apprehensive is common saying. In principle they all mean to bring an end [to selfish desires]. In no circumstances can one not be attentive, cautious, fearful, and apprehensive; and in those secret and minute places that people so easily neglect one must be even more cautious. This indeed is meant as a saying to awaken [people to this need]. (Zhu 1992a: 980-982)

Here, ZHU Xi obviously takes the phrase, "the profound person does not wait till he sees things to be cautious, nor till he hears things to be apprehensive," and the phrase, "nothing more visible than what is secret, and nothing more manifest than what is minute," as two separate things. The first is "before joy, anger, sorrow, and pleasure 
come about, or before all things sprout forth," one should "...stop them before they take their course." The latter is to "scrutinize them as they take their course," thereby "...stopping selfish desires before they sprout, not allowing them to grow in those secret and minute places [of the self]." Although both of these stages require "attentiveness, caution, fearfulness, and apprehensiveness," the latter, however, is more "anxious." "Cautious solitude" is spoken about primarily referring to this latter stage. This understanding of ZHU Xi not only ruptures the organic integrity of shendumaking it impossible for people to connect it with "sincerity"-but similar to his interpretation of the Daxue, it takes one segment of shendu and makes it out to be the entirety, thereby diminishing the original meaning of shendu.

\section{The Distinctive Meaning of Shendu in ZHU Xi's Interpretation of Classical Learning}

ZHU Xi's interpretation of shendu not only reflects the complex transformation of the meaning of shendu, but from another angle it also provides us with a further understanding of ZHU Xi's interpretation of classical learning. Similar to Confucians of the Han and Tang 唐 dynasties, ZHU Xi and other Neo-Confucians of the Song 宋 and Ming 明 dynasties expressed their own thoughts through an interpretation of the classics. It can be said that both groups fall into the category of the intellectual history of classical learning. However, the annotations of the Neo-Confucians are not like the Han and Tang Confucians in that the latter were satisfied by simply annotating and exegeting the classics; whereas the former paid more attention to developing the extending meanings of the doctrines. ZHU Xi said, "In studying books, observe the intent of the sages and worthies. By means of their intent, one observes the principle of being self-so" (Zhu 1992b: 128). The notions of "the intent of the sages and worthies" and "the principle of being self-so" (i.e., the principle of Heaven and earth) found in the classics are nothing more than the highest truths the Neo-Confucians sought. So ZHU Xi's annotations are not confined by the specific sentences and words of the classics and their commentaries; rather they pay more attention to the holistic needs of Neo-Confucian doctrine. ZHU $\mathrm{Xi}$ established the theoretical framework for notions such as principle and qi (liqi 理氣), the heart/mind and human nature (xinxing 心性), and the investigation of things and the extension of knowledge (gezhi 格致), and also implemented this theoretical framework in a specific interpretation of the classics. In order to satisfy the needs of their tenets, even to the point of not hesitating to enact an alteration, or "distortion" of the classics, ZHU Xi separated the Daxue into sections of scripture and commentary. His rearranging the "investigation of things" (gewu 格物) passage in the Daxue is a typical example. ${ }^{3}$

However, from the point of view of the interpretation provided above of shendu, ZHU $\mathrm{Xi}$ is not completely ignoring an exegesis of the Chinese characters; but rather is similarly taking shendu as an essential method of arriving at "the intent of the sages and worthies" and "the principle of Heaven." ZHU Xi's interpretation of shendu really is not a development or alteration of theoretical necessity; rather it is a "misreading" as a result of the situation of losing the original meaning of shendu, or the result of excessively adhering to the past exegesis of the Chinese characters. The original meaning of shendu might

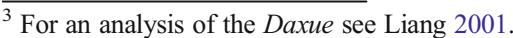


actually accord more with ZHU Xi's thinking, and might more easily be accepted by ZHU $\mathrm{Xi}$. For instance, in his method of cultivation ZHU Xi emphasized, "abiding in reverence and enriching the self” (jujing hanyang 居敬涵養)—taking “the work of being reverent (jing 敬) as the first step through the sage's door" (Zhu 1992b: 166).

According to CHENG Yi's 程頣 interpretation, being reverent means “focusing on oneness" (zhu yi 主一):

Someone asked about reverence. The master replied, "Focusing on oneness can be called reverence." The question was then put forth, "What does oneness mean?" The master responded, "Being without fixation can be called oneness." A further question was asked, "How is it possible to obtain oneness and focus on it?" The master replied, "If one is respectful and orderly, his heart/mind will be preserved. If one enriches himself and becomes well versed, his principle will shine forth." (Cheng and Cheng 1981: 1173)

ZHU Xi inherited CHENG Yi's formulation, "Reverence is the method of always being solemn. ... If one is able to compose his heart/mind, not being bothered by a single thing, he can then be called reverent" (Zhu 2010: 708). The notion of "always being solemn" means to be cautious and fearful, or reverent. The notion of "composing one's heart/mind" means to "collect one's refined spiritual powers and focus on them," not being like "the people of today, who regularly unbridle their bodies and heart/minds." ZHU Xi also said, "An explanation for holding fast to reverence does not require many words. Do no more than continuously reflect on its meaning; be orderly and solemn; be respectful, full of awe, and serious; make one's movements with proper decorum, order one's thoughts and considerations, and square one's clothes and cap.... When the body and heart/mind are in strict accordance, the interior and exterior will be singular" (Zhu 2010: 2972). To him this meant that one's focus and concentration of mental thoughts should be expressed on one's exterior countenance - to the point of uniformity between the internal and external. In the realm of psychology, this is similar to the interpretation of shendu found in the Wuxing, where it was understood as "being able to be one."

ZHU Xi extended the dictum of the heart/mind passed on from Yao 堯 to Shun 舜 and stated:

The saying, "The heart/mind of human beings (renxin人心) is precarious. The heart/mind of the Way (daoxin 道心) is minute. Refine it. Make it one. Truly hold fast to the mean." This refers to the secret idea that Yao, Shun, and Yu 禹 each passed on to each other. ... If one only occasionally eliminates the human heart/ mind, and relies on it through the normal course of daily events, then will it not simply be good fortune when relying on the minuteness of the heart/mind of the Way to not eliminate it for more than a second? (Zhu 2010: 1586)

Because the heart/mind of human beings is easily attracted by external things and has a tendency to be caught up in what is not good, it is considered "precarious." The heart/ mind of the Way is buried and concealed in the deep recesses of the internal heart/mind; being subtle and difficult to be seen, it is "minute." In order not to give free rein to the heart/mind of human beings and allow it to obliterate "the dictum of the heart/mind passed down from Yao to Shun" one must, in vigilant trepidation and fear, perform the 
sagely work of "refining it and making it one." This has some resonance with the notion of "internalizing the heart/mind" in the "Liqi."

In his theory of cultivation, ZHU Xi does not necessarily make a connection with the notions of a solitary dwelling or dwelling in solitude. The preconceived idea of a solitary dwelling or dwelling in solitude, which ZHU Xi finds so difficult to abandon, is obviously related to the efforts of earlier interpreters and to the lost transmission of $d u$ - an understanding rediscovered in the Wuxing and other ancient material. This explains that while ZHU Xi put forth and emphasized an interpretational dimension of "the intent of the sages and worthies, or the principle of Heaven and earth," at the same time he also preserved an understanding based on a close reading of "the text and language." However, in comparing it with past interpretations, the latter ("text and language") took a secondary or subordinate position; and the former ("the intent of the sages and worthies, or the principle of Heaven and earth") became the highest purpose and final conclusion in the interpretation of classical learning.

Acknowledgments I would like to thank Michael Ing for translating this article. Ing is an assistant professor in the Department of Religious Studies at Indiana University.

Open Access This article is distributed under the terms of the Creative Commons Attribution License which permits any use, distribution, and reproduction in any medium, provided the original author(s) and the source are credited.

\section{References}

Ancient Literature Research Office of State Cultural Relics Bureau 國家文物局古文獻研究室, ed. 1980. Ma Wang Dui Han Tomb Texts (I) 馬王堆漢墓帛書[壹]. Beijing 北京: Wenwu Chubanshe 文物出版社.

Cheng, Yi 程頣, and CHENG Hao 程影. 1981. The Collection of Cheng Brothers 二程集, Book 4. Beijing 北京: Zhonghua Shuju中華書局.

Editorial Division of Sea of Words 《辭海》編輯部, ed. 1965. Sea of Words 辭海. Beijing 北京: Zhonghua Shuju 中華書局.

Editorial Division of Source of Words 《辭源》編輯部, ed. 1997. Source of Words 辭源. Beijing 北京: Shangwu Yinshuguan 商務印書館.

Holloway, Kenneth. 2002. The Recently Discovered Confucian Classic “The Five Aspects of Conduct.” Ph.D. dissertation, University of Pennsylvania.

Jingmen Museum 荊門市博物館, ed. 1998. Guodian Bamboo Slips 郭店楚墓竹簡. Beijing 北京: Wenwu Chubanshe 文物出版社.

Legge, James, trans. 1971. The Four Books. Taipei: Yishi Press.

Liang, Tao 梁濤. 2000. “The Guodian Bamboo Texts and The Doctrine of the Mean 郭店竹簡與〈中庸〉公 案.” Historical Inquiry of National Taiwan University 台大歷史學報 25: 25 - 52.

2001. “A New Explanation to The Great Learning-Its Position in Intellectual History〈大學〉早出新 證.” History of Chinese Philosophy 中國哲學史 23: 71-91.

2002. “Xunzi and The Doctrine of the Mean 荀子與〈中庸〉." Journal of Graduate School of Chinese Academy of Social Sciences 中國社會科學院研究生院學報 5: 73-78.

Liu, Xiang 劉向. 1985. Garden of Persuasions 說苑. In The First Collection of Book Series 叢書集成初編. Beijing 北京: Zhonghua Shuju 中華書局.

Watson, Burton, trans. 1968. The Complete Works of Chuang Tzu. New York: Columbia University Press.

Xun, Kuang 荀況. 2005. Xunzi 荀子. Shanghai 上海: Shanghai Guji Chubanshe 上海古籍出版社.

Zheng, Xuan 鄭玄. 1980. The Annotation of the Book of Rites 禮記正義. In The Exegesis of the Thirteen Confucian Classics 十三經注疏. Beijing 北京: Zhonghua Shuju 中華書局.

Zhu, Xi 朱喜. 1992a. ZHU Xi's Sayings of the Four Books 朱子四書語類. Shanghai 上海: Shanghai Guji Chubanshe 上海古籍出版社.

1992b. ZHU Xi's Sayings of Xingli 朱子性理語類. Shanghai 上海: Shanghai Guji Chubanshe 上海古籍出版社. 1994. Collected Annotations of the Four Books 四書集注. Beijing 北京: Zhongguo Shudian 中國書店. 2010. Complete Works of ZHU Xi 朱子全書. Shanghai 上海: Shanghai Guji Chubanshe 上海古籍出版社. 